\title{
Recenzja: S. Salmonowicz, Polniscbe Preussen oder Westpreussen. Ausgewäblte Studien, Instytut Kaszubski, Gdańsk 2018, ss. 159
}

\author{
Abstract \\ Review: S. Salmonowicz, Polnische Preussen oder Westpreussen. Ausgewäblte Studien, \\ Instytut Kaszubski: Gdańsk 2018, 159 p.
}

In 2018, Prof. Stanisław Salmonowicz, published his latest book entitled Polish Prussia or West Prussia. Selected Studies (Kashubian Institute in Gdańsk). It consists of the author's biography and eight texts published in the last 30 years. The key binding individual works together is the subject of Prussia, in which Prof. Salmonowicz specializes and is an undisputed academic authority. They raise the issue of relations between Royal Prussia and the Crown, the role of Königsberg in the era of Enlightenment, the functioning of the Academic Schools in Prussia and their importance for the identity of its inhabitants, the language in everyday life of early modern Torun, the culture of Pomerania, and the image of Poland as seen through the eyes of Georg Forster. Assembling these broad elements into a single publication provides a major asset for researchers dealing with Prussian issues in general, and more broadly, with modern history.

Keywords: Prussia, Enlightenment, Toruń

Słowa kluczowe: Prusy, Oświecenie, Toruń

W 2018 r. nakładem Instytutu Kaszubskiego w Gdańsku ukazał się najnowszy wybór studiów Profesora Stanisława Salmonowicza pt. Polnische Preussen oder Westpreussen. Ausgewählte Studien. Składa się on z biogramu autora oraz jego ośmiu tekstów opublikowanych w ostatnich trzydziestu latach, głównie w wydawnictwach niemieckich. Siedem z nich (oraz biogram) zostało wydanych w języku niemieckim, jeden zaś w języku angielskim. Klucz wiążący poszczególne prace stanowi tematyka Prus, w której prof. Salmonowicz się specjalizuje i jest niekwestionowanym autorytetem naukowym. Poruszają one kwestię relacji Prus Królewskich z Koroną, roli Królewca w dobie oświe- 
cenia, funkcjonowania Gimnazjum Akademickiego w Toruniu i znaczenia szkół półwyższych prowincji dla tożsamości jej mieszkańców, języka w życiu codziennym wczesnonowożytnego Torunia, kultury Pomorza i obrazu Polski widzianego oczami Georga Forstera. W sumie publikacja liczy 159 stron.

Biogram zatytułowany Stanisław Salmonowicz - ein Historiker von der Gesellschaftsordnung und der Kultur vom Königlichen Preußen (Polnisch-Preußen) und Herzogtum Preußen (Ostpreußen) (s. 7-10) opracował inny uznany badacz Prus Królewskich, Jerzy Dygdała. Przedstawiono w nim najważniejsze fakty z życia i kariery naukowej autora, w szczególności skupiając się na jego zainteresowaniu tematyką pruską oraz pracach będących tego rezultatem. Warto przypomnieć, że prof. Salmonowicz jest autorem bądź współautorem prawie 100 książek naukowych i popularnonaukowych oraz ok. 1000 artykułów i opracowań, które opublikował w językach polskim, niemieckim, francuskim i angielskim (s. 10). Na uwagę zasługuje przy tym niezwykle szeroki zakres podejmowanych przez niego tematów badawczych. Wśród głównych, jakie pojawiają się na stronach jego prac, można wyróżnić m.in. historię prawa, administracji, ustroju czy szeroko rozumianej kultury, nauki i społeczeństwa. Wiele uwagi w swoim dorobku poświęcił on też Toruniowi, z którym jest zawodowo związany od drugiej połowy lat 60 . Co ważne, wiele pozycji S. Salmonowicza - w tym monografie poświęcone Gimnazjum Akademickiemu w Toruniu (Toruńskie Gimnazjum Akademickie w latach 1681-1817, Poznań 1973), Fryderykowi II Wielkiemu (Fryderyk II Wielki, Wrocław 1981, 1985, 1998, 2006) czy prawu karnemu okresu oświeconego absolutyzmu (Prawo karne oświeconego absolutyzmu. Z dziejów kodyfikacji karnych przelomu XVIII-XIX w., Toruń 1966) - na stałe weszło do kanonu polskiej i europejskiej historiografii.

$\mathrm{W}$ pierwszym z zamieszczonych w wyborze artykułów pt. Königliches Preußen und polnisch-litauischer Staat (1466-1772) (s. 11-23) zostały omówione stosunki Prus Królewskich z Koroną. Analiza tej problematyki objęła cały okres istnienia prowincji, tj. od inkorporacji terytorium pruskiego w 1466 r. do Królestwa Polskiego, do pierwszego rozbioru państwa w 1772 r., kiedy to niemal całe terytorium Korony zostało przejęte przez Królestwo Prus. Autor przedstawił pozycję prowincji w strukturach państwa oraz wynikłe stąd konsekwencje. Podkreślił istnienie różnych punktów widzenia na sprawę Prus - nakreślił zarówno spojrzenie polskie, litewskie, jak i pruskie, a także pojawiające się w czasie różne koncepcje co do statusu Prus Królewskich wraz z ich odrębnościami, odróżniającymi je od innych części Korony.

Kolejny artykuł, Königsberg, Thorn und Danzig. Zur Geschichte Königsbergs als Zentrum der Aufklärung (s. 37-58) został poświęcony jednemu z najważniejszych miast Prus Książęcych, a następnie Królestwa Prus, Królewcowi. Autor ukazał je jako centrum oświecenia w regionie, głównie w kontekście dwóch innych, znaczących gmin, tj. Torunia i Gdańska. Warto jednak zwrócić uwagę, że sporo jego ciekawych spostrzeżeń dotyczy również trzeciego z wielkich miast Prus Królewskich, Elbląga. Po uwagach wstępnych na temat historii i sytuacji Królewca w XV-XVIII w. Salmonowicz przedstawił problematykę życia duchowego gminy pierwszej połowy XVIII w., z wpływającym w tym czasie na luteranizm pietyzmem. W dalszej części przeanalizowane zostały kontakty między królewieckimi, gdańskimi i toruńskimi uczonymi, ich prace, zakładane w tym czasie naukowe stowarzyszenia oraz czasopisma. Podkreślone zostało przy tym znaczenie królewieckiej Alma Mater w XVIII w. Z uwagi na swoje położenie oraz 
konfesję elit miejskich Prus Książęcych i Królewskich Uniwersytet w Królewcu był bowiem naturalnym kierunkiem edukacji dla wychowanków pruskich szkół półwyższych. Osobną uwagę autor poświęcił pisarzom i publicystom okresu. Na koniec przedstawił rolę Królewca dla ówczesnej kultury i rozwój relacji z innymi gminami po pierwszym rozbiorze Polski (1772).

Sporą część wyboru stanowią artykuły poświęcone gimnazjom akademickim Prus Królewskich. W tekście Rechtslehre und Rechtswissenschaft am Thorner Gymnasium Academicum im 17. Jahrhundert (s. 24-36) S. Salmonowicz omówił nauczanie prawa w założonym w 1568 r. gimnazjum toruńskim. Skupiając się na XVII w., autor dokonał jednocześnie podziału tego okresu na dwa mniejsze, tj. do $1660 \mathrm{r}$. i od 1660 do 1706 r. Pierwszy z nich był czasem rozkwitu dla szkoły i zakończył się w okresie potopu szwedzkiego (1655-1660). Drugi przyniósł zahamowanie rozwoju placówki, choć i w nim Toruń odgrywał ważną rolę w nauczaniu akademickim młodzieży z Prus i spoza prowincji (s. 79). W artykule przedstawiono system nauczania prawa, sylwetki wybranych profesorów, wykształconych w niej absolwentów, jak również realizowane w gimnazjum kierunki nauczania i podejmowane problemy badawcze. Dziejom toruńskiej szkoły półwyższej w XVII i XVIII w. autor poświęcił uwagę w tekście Das protestantische Gymnasium Academicum in Thorn im 17. und 18. Jahrhundert (s. 76-92). Tekst ten stanowi szersze ujęcie tematu, wychodząc poza problematykę ściśle związaną z prawem i jego nauczaniem, obejmując także inne gałęzie nauki. Posiada on też rozleglejsze ramy czasowe. Te ostatnie podzielono na trzy okresy, tj. wspomniany już czas rozkwitu do 1660 r., okres baroku i wczesnego oświecenia od 1660 do 1745 r., oraz lata 1745-1793, kiedy to szkołę dotknął spadek liczby studentów oraz kryzys finansów miasta zakończony drugim rozbiorem Polski (1793) oraz przyłączeniem Torunia do Królestwa Prus (s. 79). Podobnie jak w przypadku artykułu Rechtslehre und Rechtswissenschaft omówił w nim najważniejsze dokonania oraz największe problemy środowiska gimnazjum, nie stroniąc od uwag ogólnych, które odnieść można do pozostałych szkół półwyższych prowincji. Szerzej problem znaczenia gimnazjów akademickich dla Prus Królewskich Salomonowicz rozwinął w tekście Die protestantischen akademischen Gymnasien in Thorn, Elbing und Danzig und ihre Bedeutung für die regionale Identität im Königlichen Preußen (16-18 Jahrhundert) (s. 93-119). Interesująca jest również rola gimnazjów w kontekście regionalnej tożsamości mieszkańców prowincji (s. 94). Do najważniejszych czynników mających znaczenie i wpływających na samoświadomość ludności tego terytorium w XVI i XVII w. zaliczyć można m.in. konfesję, język, świadomość pochodzenia etnicznego, prawo czy uzyskane na mocy przywilejów wolności. Nie bez wpływu na tę kwestię była jednak również działalność gimnazjów w Toruniu, Elblągu i Gdańsku (s. 94-95). Autor rozpoczął swoje rozważania od krótkiej charakterystyki badań nad wspomnianymi szkołami półwyższymi. Następnie przedstawił ogólne i szczegółowe uwagi na temat świadomości mieszkańców wielkich i mniejszych miast pruskich, by w dalszej części zając się problemem roli gimnazjów w ich otoczeniu oraz, poprzez ich działalność, wpływem, jakie posiadały one na budowanie tożsamości regionalnej. Jak podkreślił prof. Salmonowicz, nie można nie zauważyć znaczenia tych ośrodków nauki dla rozpatrywanego tematu i to - jak pokazała zaprezentowana przez niego analiza - zarówno w kontekście lokalnym (gdańskim, toruńskim czy elbląskim), jak i szerszym, prowincjonalnym (s. 119). 
Osobny tekst autor poświęcił Georgowi Forsterowi (1754-1794) (Georg Forster und sein Polenbild: Kosmopolitismus und nationales Stereotyp, s. 59-75). Forster był przyrodnikiem, etnologiem, profesorem historii naturalnej i podróżnikiem, związanym z Prusami Królewskimi, gdzie się urodził (Nassenhuben/Mokry Dwór). Jego ojcem był Johann Reinhold Forster (1729-1798), uznany badacz historii naturalnej i podróżnik. Dzięki niemu Georg już od najmłodszych lat uczestniczył w wyprawach badawczych i ukierunkował swoje zainteresowania naukowe. Interesujący dla autora jest prezentowany w pismach Forstera obraz Polski. Dzięki zestawieniu kolejnych wydarzeń z życia przyrodnika z informacjami pochodzącymi z pozostawionych przez niego źródeł pisanych (opublikowanych zarówno za jego życia, jak i upublicznionych po śmierci), Salmonowicz przedstawił go z punktu widzenia nie tylko mieszkańca Prus (o szkocko-niemieckim pochodzeniu), ale również kosmopolity, z krytycznym spojrzeniem na otaczający go świat i Polskę. W zakończeniu artykułu autor poczynił szereg ogólnych uwag na temat prezentowanej przez Forstera krytyki i jej charakteru (s. 74-75).

Tematem kultury Pomorza autor zajął się w artykule The Culture of Eastern Pomerania at the Threshold of the Modern Era (s. 120-145). Zauważył, że pomimo istotnych podziałów występujących na tym terenie (politycznych, ekonomicznych czy religijnych) istniał jeden czynnik łączący wszystkie terytoria - Pomorze, które z jego portami stanowiło swoiste okno na świat ze wszystkimi tego konsekwencjami. Porty odgrywały przy tym nie tylko funkcje ekonomiczne, ale też kulturalne, także dzięki ułatwionej komunikacji z innymi państwami. Najlepszym przykładem był leżący w dawnym województwie pomorskim Gdańsk, który stanowił nie tylko największe miasto południowego Bałtyku, ale również Prus Królewskich, oraz inne tzw. wielkie miasta prowincji, tj. Toruń i Elbląg (s. 120). Podobną, choć nie równoważną, funkcję w Prusach Książęcych pełnił Królewiec, a na Pomorzu Zachodnim Szczecin czy Kołobrzeg. Autor dokonał analizy zagadnienia kultury pod kątem struktury etnicznej, konfesyjnej, ekonomicznej i językowej. Osobną uwagę poświęcił problemowi wpływów polskich i niemieckich na Pomorzu. Jak zauważył, na tych terenach doszło do połączenia kultury polskiej i niemieckiej, a także do rywalizacji między nimi. Umocnienie się tej ostatniej poprzez reformację w XVI w., spowodowało spadek znaczenia wpływów polskich, które odtąd były identyfikowane powszechnie z kulturą katolicką. Warto jednak pamiętać, że w skali globalnej Pomorze było też pośrednikiem dla obu kultur. Największą rolę odgrywały w tym Prusy Królewskie, mniejszą zaś Pomorze Zachodnie i Prusy Książęce (s. 127129). Nie bez znaczenia dla kultury Prus były też wpływy niderlandzkie. W szczególności dotyczyło to okresu od połowy XVI do połowy XVII w., kiedy to kontakty i wymiana z Holandią przewyższyły nawet stosunki z Anglią, Francją czy krajami niemieckimi (s. 145). Inną kwestię stanowiły w dotychczasowych badaniach kultura materialna i intelektualna. Autor podkreślił, że pomimo istotnego rozwoju nauki, wiele problemów wiążących się z nimi wciąż czeka na szczegółowe opracowanie. Przykładem może być kultura intelektualna końca XVII i początków XVIII w., która poza największymi z pruskich miast, czyli Gdańskiem i Toruniem, wymaga dalszych badań (s. 131-132, 145). Tym bardziej że w wiekach XVI-XVIII obserwowano jej dynamiczny rozwój na terenie Pomorza np. w zakresie przemysłu wydawniczego, nauki, edukacji, teatru czy rzemiosła artystycznego (s. 133). 
Problematykę kultury prof. Salmonowicz kontynuuje w tekście Die Sprachen der Kultur und des Alltagslebens in Thorn im 17.-18. Jh (s. 146-159). Po uwagach wstępnych dotyczących specyfiki miasta, mieszkańców i ich języka autor przeanalizował szczegółowe kwestie dotyczące roli tego ostatniego w życiu codziennym. Jako pierwszy omówił problem języka urzędowego. Tym był język niemiecki, na który przetłumaczone były stosowane w Toruniu źródła prawa chełmińskiego. Jednocześnie ordynacje, którymi regulowano poszczególne dziedziny życia miejskiego, ogłaszano również w języku polskim (s. 149-150). Ten ostatni był również stosowany w kontaktach z władzami miejskimi oraz w postępowaniach sądowych. Językiem źródeł prawa był jednak także język łaciński (s. 150). W dalszej części autor omówił strukturę życia kulturalnego w mieście i powiązane z nią konsekwencje językowe. W swoich rozważaniach uwzględnił rolę Gimnazjum Akademickiego, Kolegium Jezuickiego oraz pozostałych, funkcjonujących w mieście szkół, rynku drukarskiego, kościołów czy działalności wykształconych elit miejskich (Gelehrten). Tekst zakończyło podsumowanie wraz z postulatami w zakresie dalszych badań nad kulturą Torunia.

Podsumowując, najnowsza książka Stanisława Salmonowicza to udany wybór jego prac dotyczących głównie Prus Królewskich i Książęcych. Zebranie ich w jednej publikacji stanowi duży atut dla badaczy zajmujących się tematyką pruską i, szerzej, historią nowożytną. Różnorodność rozpatrywanych problemów badawczych pozwala przypuszczać, że wybór zainteresuje zarówno historyków ogólnych oraz osoby specjalizujące się $\mathrm{w}$ historii prawa, nauki czy kultury. $\mathrm{Z}$ uwagi na podjęte $\mathrm{w}$ nim tematy ma on też niezaprzeczalny walor dla badań porównawczych wykraczających daleko poza granice Prus. Co warto również podkreślić, dzięki przetłumaczeniu tekstów na język niemiecki publikacja będzie stanowić doskonałe narzędzie w popularyzacji wyników polskich badań w nauce niemieckiej i wśród badaczy posługujących się tym językiem. 